\title{
Cell spreading on laminin substrate involves Con A-binding proteins
}

\author{
R Moutsita *, J Botti, MA Doyennette-Moyne, \\ M Aubery, P Codogno \\ INSERM U. 180, UFR Biomédicale des Saints-Pères, Laboratoire de Biologie \\ et Pathologie Moléculaires des Glycoprotéines, 45, rue des Saints-Pères, 75006 Paris, France
}

(15th meeting of the INRA development group, Paris, 24-26 May 1989)

\begin{abstract}
Summary - Concanavalin A (Con A), a tetravalent lectin, was shown to impair 8 chick embryo fibroblast (8 d CEF) spreading on a laminin (LM) substrate but not on a fibronectin substrate (FN), suggesting that cell surface Con $A$ binding proteins could be involved in $8 \mathrm{~d} C E F$ spreading on a $L M$ substrate. The interaction of Con A-binding proteins with Con $A$ is dependent upon the carbohydrate moieties of the isolated glycoproteins; since they interact strongly with Con A-Sepharose and are eluted with $0.3 \mathrm{Mol} / \mathrm{\alpha} \alpha$-methylmannopyranoside, the isolated Con A binding-proteins inhibit $8 \mathrm{~d}$ CEF adhesion to a Con $A$ substrate to the same extent as $\alpha$-methylmannopyranoside. Furthermore, the isolated Con A binding proteins specifically inhibit in a dose-dependent manner $8 \mathrm{~d}$ CEF spreading on LM but not on FN.
\end{abstract}

fibroblast / Con A-binding site / adhesion / laminin / fibronectin

Résumé - L'étalement des cellules sur la laminine impllque des protéines fixant la Con A. La concanavaline A (Con A), lectine tétramérique, empêche l'étalement des fibroblastes d'embryons de poulet âgés de 8 jours (8d CEF) sur un support de laminine, mais pas sur un support de fibronectine. Ceci suggère que les protéines membranaires fixant la Con A seraient impliquées dans l'étalement des fibroblastes sur la laminine. L'intéraction de ces protéines avec la Con A dépend des chaînes oligosaccharidiques des glycoprotéines isolées qui réagissent fortement avec la Con ASépharose et sont éluées par l' $\alpha$-méthylmannopyranoside $(0,3$ mol/). Les protéines fixant la Con $A$. Ces protéines fixant la Con A inhibent spécifiquement l'étalement des fibroblastes sur laminine mais pas sur fibronectine.

fibroblaste / site Con A / adhésion / laminine / fibronectine

\footnotetext{
* Correspondance and reprints
} 


\section{INTRODUCTION}

The interaction between cells and the extracellular matrix is a multiple step phenomenon (Aplin and Hughes, 1981). The initial attachment of cells to the extracellular matrix is followed by a spreading period. This latter process requires a rearrangement of intracellular cytoskeletal components which leads to a drastic change in cell morphology together with topological modifications of the cell surface. Results recently obtained in our laboratory show that 8-d-old chick embryo fibroblasts ( $8 \mathrm{~d}$ CEF) use different mechanisms to attach and spread on fibronectin (FN) and laminin (LM). We have shown that the lectin concanavalin A (Con A) impaired spreading on a $\mathrm{LM}$ but not on a $\mathrm{FN}$ substrate (Codogno et al, 1988a). To ascertain the role of some cell surface glycoproteins in the spreading of CEF onto $L M$, we used the tetrameric lectin Con $A$ as a tool. Therefore, in this study, we carried out experiments to investigate the nature of the interaction between Con $A$ and $8 \mathrm{~d}$ CEF Con A-binding sites, and the role of Con A binding sites during the cell spreading on laminin.

\section{MATERIALS AND METHODS}

\section{Cell culture}

Primary monolayer cultures of fibroblasts were established from 8-d-old chick embryos. Cells were used before confluence and were obtained by TPCK-trypsin treatment, as previously reported (Codogno et al, 1988a).

\section{Adhesion assay and cell spreading}

FN and LM substrates were prepared as detailed previously (Codogno et al, 1987). Negative controls of adhesion were performed using plates coated with $2 \%$ bovine serum albumin
(BSA). At the end of the adhesion assay (Rou tinely $2 \mathrm{~h}$ ), the plates were washed 3 times with PBS. Cell attachment and spreading were determined by direct microscopic observation of different fields.

\section{Cell surface Con A-binding protein isolation}

Con A binding protein isolation was conducted after metabolic labelling with [35-S]methionine ( $50 \mu \mathrm{Ci} / \mathrm{ml}$, sp act $1200 \mathrm{Ci} / \mathrm{mmole}$, CEA Saclay) for $16 \mathrm{~h}$, as previously described (Nowakoski et al, 1987; Codogno et al, 1988a). Labelled Con A-binding proteins were diluted in PBS, pH 7.4, at the required concentration and added at the beginning of the adhesion assay. Similarly, $\alpha-$ methylmannopyranoside $(0.1 \mathrm{~mol} / \mathrm{/})$ and ovalbu$\min (5-40 \mu \mathrm{g} / \mathrm{ml})$ from Sigman, La Verpillère were added at the beginning of the adhesion assay.

\section{Con A-Sepharose chromatography of isolated Con A binding proteins}

Chromatography on Con A-Sepharose (Pharmacia, Bois d'Arcy) was conducted at room temperature, as previously reported (Codogno et al, 1985), on a $1 \times 5 \mathrm{~cm}$ column. Con A binding proteins $(30000 \mathrm{cpm})$ were loaded on a column equilibrated with $0.025 \mathrm{~mol} / \mathrm{l}$ Tris- $\mathrm{HCl}, \mathrm{pH} 7.5$ containing $0.1 \mathrm{~mol} / \mathrm{NaCl}$ and $10^{-3} \mathrm{~mol} / \mathrm{CaCl}_{2}$, $\mathrm{MgCl}_{2}$ and $\mathrm{MnCl}_{2}$. Elution was performed with the same buffer containing successively: 0.01 $\mathrm{mol} / \mathrm{l} \alpha$-methylglucopyranoside and $0.3 \mathrm{~mol} / \mathrm{l}$ $\alpha$-methylmannopyranoside. The radio-activity was determined in a counter Minaxi $\beta 4000$ (Packard) equipped with a dpm calculation program. More than $90 \%$ of the radioactivity loaded was recovered.

\section{RESULTS}

\section{Isolation of Con A binding sites}

Con A-binding sites were isolated from CEF labelled with [ ${ }^{35}$ S]methionine incubat- 
ed with biotinylated-Con $A$, and then extracted with $n$-octylglucoside. The resulting soluble material was subsequently subjected to chromotography on avidin-Agarose. The radioactivity recovered in the eluted fraction accounted for $17 \%$ of the loaded radioactivity. Polyacrylamide gel electrophoresis and fluorography of the Con Abinding proteins revealed glycoproteins ranging from $30-72 \mathrm{kDa}$.

\section{Relation between cell surface Con $A$ binding sites and Con A specificity}

Two sets of experiments were designed to determine the specificity of the Con A binding sites for the Con A lectin.

- When isolated, Con A binding sites were subjected to chromatography on a Con A-Sepharose column; all the radioactivity was eluted with $0.3 \quad M \quad \alpha$ methylmannopyranoside,

- When CEF were plated on a Con A substrate, the cell adhesion curve reached a

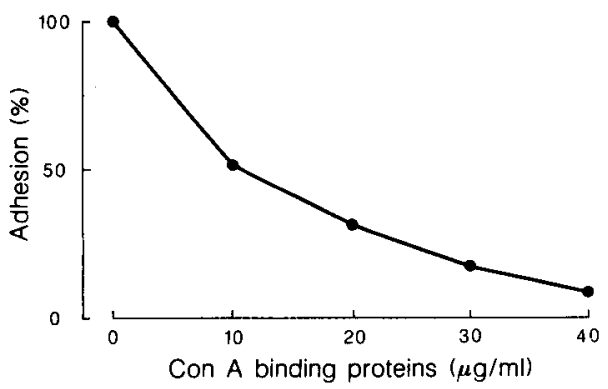

Fig 1. Effect of Con A-binding proteins on CEF adhesion to a Con $A$ substrate. Con $A$ was coated at a concentration of $50 \mu \mathrm{g} / \mathrm{ml}$ as described under Materials and Methods. Con A-binding proteins were added at the beginning of the adhesion assay. Cells were incubated for $2 \mathrm{~h}$ at 37 ${ }^{\circ} \mathrm{C}$ and the number of cells attached were scored after 3 washes to remove non-adherent cells and fixation with $2.5 \%$ glutaraldehyde. plateau when $50 \mu \mathrm{g} / \mathrm{ml}$ of Con A were used (data not shown). The adhesion could be almost completely inhibited with $0.1 \mathrm{~mol} / \mathrm{l} \alpha$-methylmannopyranoside (90\% inhibition). Con A-binding sites blocked, in a dose-dependent manner, CEF adhesion to Con A (fig 1). This inhibition was not related to the presence of detergent since dialyzed extract, under the same conditions and added to a cell suspension in a control experiment, did not alter CEF adhesion capacities. These 2 experiments argue for the specificity of the Con A-binding glycoproteins for the Con A lectin.

\section{Isolated Con A binding sites inhibit CEF spreading on LM}

Con A was shown to specifically impair CEF spreading on LM, whereas no such phenomenon was observed on FN. Isolated Con A-binding proteins did not affect either CEF attachment on an LM or FN substrate in the range of concentrations used $(0.5-5 \mu \mathrm{g} / \mathrm{ml})$. The presence of free Con Abinding proteins did not modify the spreading of CEF on an FN substrate even when lower quantities of coating $\mathrm{FN}$ were used (data not shown). Conversely, Con Abinding proteins inhibited CEF spreading on LM in a dose-dependent manner (table I). The inhibition of CEF spreading was complete when $3 \mu \mathrm{g} / \mathrm{ml}$ of Con A-binding proteins were added to the adhesion medium. The induced effect was not due to the presence of small quantities of detergent associated with the Con A-binding proteins since the control buffer (see above) did not perturb CEF spreading on LM (table I). The specificity of the effect was verified using an irrevalent Con A-binding protein, $i e$, ovalbumin, in the concentration range used from 5-40 $\mu \mathrm{g} / \mathrm{ml}$, which did not modify the CEF spreading on LM (table I). 
Table I. Effect of Con A-binding proteins on $8 \mathrm{~d}$ CEF spreading on LM and FN substrates. Routinely, spreading was visualized after $2 \mathrm{~h}$ of incubation at $37^{\circ} \mathrm{C}$. Under these conditions, the same number of cells were attached to LM and FN substrates. Spreading was quantified as follows: $100-200$ cells were scored under microscopic observation. $+: 100 \%$ of spreading; $+1-: 50 \%$ of spreading; $--:$ no spreading, ie, round cells.

$\begin{array}{lcc}\text { Con A-binding } & \text { Dialysed } & \text { Ovalbumin } \\ \text { proteins } \mu \mathrm{g} / \mathrm{ml} & \text { extract } & 40 \mu \mathrm{g} / \mathrm{ml}\end{array}$

$1 \quad 2 \quad 5$

$\begin{array}{llllll}\text { Spreading on LM } & + & +1- & - & + & + \\ \text { Spreading on FN } & + & + & + & + & +\end{array}$

\section{DISCUSSION}

The nature of molecular events leading to cell spreading, after the initial interaction between extracellular matrix receptors and their ligands, remains poorly understood. Using Con A, we have shown that this lectin specifically impaired 8 d CEF spreading on LM substrate (Codogno et al, 1988a). Although, Dean et al (1988) have shown that Con $A$ binding to $L M$ impaired $B_{16} F_{1}$ cells spreading, the results presented here showed that isolated Con A binding glycoproteins inhibited CEF spreading onto $L M$, thus arguing for the role of these membrane associated glycoproteins in this phenomenon. These receptors are a heterogeneous population with molecular mass ranging from $30-72 \mathrm{kDa}$.

The Con A-binding sites interact strongly with the lectin via their carbohydrate moieties, suggesting that these receptors are decorated with $\mathrm{N}$-linked high mannose type chains. To our knowledge, these isolate Con $\mathrm{A}$ binding proteins are unrelated to the 69K LM receptor (Lesot et al, 1983) and to the extracellular matrix receptor belonging to the integrin family (Ruoslahti, 1988). Nevertheless, we cannot exclude the presence of 5 nucleotidase among the
Con A binding proteins isolated which interact with LM (Dieckhoff et al, 1986) and was shown to inhibit CEF spreading on LM (Codogno et al, 1988b). During the isolation of WGA- and Ricinus communis (RCA)-binding molecules from BHK cells, it was recently reported (Tuan and Grinnell, 1988) that these receptors account for 1.5 and $0.15 \%$, respectively, of the radioactivity recovered after detergent extraction. Herein, we show that Con A-binding molecules represent $17 \%$ of the detergent extracted material. In spite of differences in the procedures used to extract lectinbinding sites in these 2 different studies, the high quantity of Con A binding proteins isolated is in good agreement with the large number of Con $A$ binding sites on $8 \mathrm{~d}$ CEF (Bernard et al, 1982).

The isolated Con A-binding proteins inhibit in a dose-dependent manner, the spreading of $8 \mathrm{~d}$ CEF on LM but not on FN. A recent ultrastructural study reports that Con A-binding proteins are in close proximity to the cytoskeletal components and their distribution is regulated by the actin meshwork (Katsumoto and Kurimura, 1988). Furthermore, the results reported herein show direct competition between "soluble" Con A-binding proteins and mem- 
brane bound Con A-binding proteins, suggesting that these glycoproteins could interact with LM. Further studies will be addressed at elucidating the relationship between Con A-binding proteins, LM and cytoskeletal proteins.

\section{ACKNOWLEDGMENTS}

This work was supported by grants from INSERM, UFR Biomédicale des Saint-Père and Fondation pour la Recherche Médicale.

\section{REFERENCES}

Aplin JD, Hughes RC (1981) Cell adhesion on model substrata: threshold effects and receptor modulation. J Cell Sci 50, 89-103

Bernard $B$, Font $J$, Aubery $M$, Bourrillon R (1982) Influence of temperature on the interaction of concanavalin $A$ with chick fibroblasts during embryo development. Biochem Biophys Res Commun 106, 256-264

Codogno P, Botti J, Font J, Aubery M (1985) Modification of the $\mathrm{N}$-linked oligosaccharides in cell surface glycoproteins during chick embryo development. Eur J Biochem 149, 453460

Codogno P, Doyennette-Moyen M-A, Aubery M (1987) Evidence for a dual mechanism of chick embryo fibroblast adhesion on fibronectin and laminin substrata. Exp Cell Res 169, 478-489

Codogno $\mathrm{P}$, Doyennette-Moyne MA, Botti J, Aubery M (1988a) Concanavalin A-induced impairment of fibroblast spreading on laminin but not on fibronectin. J Cell Physiol 136, 463-470

Codogno P, Doyennette-Moyne M-A, Aubery M, Dieckhoff J, Lietzke R, Mannherz HG (1988b) Polyclonal and monoclonal antibodies against chicken gizzard 5'-nucleotidase inhibit the spreading process of chicken embryonic fibroblasts on laminin substratum. Exp Cell Res 174, 344-354

Dean III JW, Chandrasekaran S, Tanzer ML (1988) Lectins inhibit cell binding and spreading on a laminin substrate. Biochem Biophys Res Commun 156, 411-416

Dieckhoff J, Mollenhauer J, Kühl U, Niggemayer B, von der Mark, Mannherz HG (1986) The extracellular matrix proteins laminin and fibronectin modify the AMPase activity of $5^{\text {'- }}$ nucleotidase from chicken gizzard smooth muscle. FEBS Lett 195, 82-86

Katsumoto T, Kurimura T (1988) Ultrastructural localization of concanavalin $A$ receptors in the plasma membrane: association with underlying actin filaments. Biol Cell 62, 1-10

Lesot H, Kühl U, von der Mark K (1983) Isolation of a laminin binding protein from muscle cell membrane. EMB்O J 2, 861-765

Nowakoski BK, Ruper CA (1987) The isolation of cell surface glycoproteins from differentiated neuroblastoma NG 108-15 cells with biotinylated concanavalin A. In: Proc of the 9th Int Symp on Glycoconjugates (Montreuil J, Verbert A, Spik G, B Fournet, eds) A Lerouge, Tourcoing

Ruoslahti E (1988) Fibronectin and its receptors. Annu Rev Biochem 57, 375-413

Tuan TL, Grinnell F (1988) Wheat-germagglutinin and Ricinus communis-agglutininbinding sites of BHK cells compared with each other and with $\mathrm{kDa}$ fibronectin receptors. Biochem J 251, 269-277 